\title{
Optimization of Jatropha Biodiesel Production by Response Surface Methodology
}

\section{Nurudeen Ishola Mohammed ${ }^{1,2}$, Nassereldeen Ahmed Kabbashi1 ${ }^{1}$, Md Zahangir Alam¹, Mohamed Elwathig S. Mirghani ${ }^{3}$}

\author{
${ }^{1}$ Bioenvironmental Engineering Research Centre (BERC), Department of Biotechnology Engineering, Faculty of Engineering, \\ International Islamic University Malaysia, Jalan Gombak, Kuala Lumpur. Malaysia \\ ${ }^{2}$ Chemical and Environmental Engineering Department, School of Engineering, RMIT University, Victoria, Australia \\ ${ }^{3}$ International Institute for Halal Research and Training (INHART) (IIUM), Kuala Lumpur, Malaysia \\ Email: *sholanourou@yahoo.com, somao4all@gmail.com
}

How to cite this paper: Mohammed, N.I., Kabbashi, N.A., Alam, MdZ. and Mirghani, M.E.S. (2021) Optimization of Jatropha Biodiesel Production by Response Surface Methodology. Green and Sustainable Chemistry, 11, 23-37.

https://doi.org/10.4236/gsc.2021.111003

Received: December 28, 2020

Accepted: February 16, 2021

Published: February 19, 2021

Copyright (c) 2021 by author(s) and Scientific Research Publishing Inc. This work is licensed under the Creative Commons Attribution International License (CC BY 4.0).

http://creativecommons.org/licenses/by/4.0/

(c) (i) Open Access

\begin{abstract}
Cost of biodiesel is primarily because of factors such as the feedstock, production process and materials. Apparently, the final biodiesel product is a bit expensive compared to fossil diesel fuel. While non-food feedstock of high oil content such as Jatropha curcas has been proposed to reduce the cost due to the feedstock, a promising two-step approach of hydro-esterification can possibly offset the production cost for oil resource with high free fatty acids. Most importantly, optimization of the materials and process is expected to reduce wastage, enhance product purity and generate less wastewater. However, optimizing product generation has been dauntingly elusive because several parameters are needed to be considered holistically. In this study, Response Surface Methodology (RSM) was employed to optimize the yield and conversion of Jatropha biodiesel from J. curcas hydrolysate. An optimum Yield and conversion of $96 \%$ was achieved for both responses with an optimum temperature value of $60^{\circ} \mathrm{C}, 4 \mathrm{wt} \%$ for catalyst loading for $6 \mathrm{hrs}$ reaction time. Findings imply that optimization study of Jatropha curcas hydrolysate for yield and conversion of fatty acid methyl esters using face centered central composite design of Design Expert 6.0.8 can ensure purity of product, conserve energy and reduce waste generation providing a significant frontier in biodiesel pricing.
\end{abstract}

\section{Keywords}

Jatropha curcas, Esterification, Optimization, Yield, Conversion 


\section{Introduction}

Renewable energy is an area of alternative solution to energy problems experiencing ongoing research enquiry because it is clean and environmentally benign. Renewable energy sources (RESs) are also known to emit lower or appreciably negligible amount of greenhouse gases and other pollutants as compared with the fossil energy sources. Among the many RESs, the prospect of biodiesel is particularly promising, experiencing intensified research effort to ensure its competitiveness with the conventional energy source [1] [2] [3].

Biodiesel offered technical competition by offering technical benefits over conventional diesel fuel. Vegetable oils can be converted into their alkyl esters via transesterification process in the presence of a chemical or enzyme catalyst. These catalysts are employed due to the apparent immiscible nature of the oil-alcohol interphase [4]. Methyl, ethyl, 2-propyl, and butyl (all from short chain monohydric alcohol) esters have been prepared sourcing feedstocks from vegetable oils origin, using majorly sodium, potassium and/or sodium alkoxides as catalysts [5]. The transesterification process is aimed at reducing the viscosity of the oil. Ideally, while transesterification is potentially a less expensive way to transform the large, branched molecular structure of bio-oils into smaller, straight-chain molecules of the type required in regular diesel combustion engines, notwithstanding, cost of biodiesel is still not competitive.

The cost of biodiesel is primarily determined by the feedstock utilized in the production, accounting for between $70 \%$ - 95\% of overall production cost [6] [7]. Of importance are the geographic location, diversity in crop cultivation, the cost of fossil fuel, and some other factors in biodiesel price determination. Currently, high purity requirement of oil resource for biodiesel is responsible for the high price of biodiesel. However, low-cost feedstocks of solid state such as tallow, lard, and grease [8], waste cooking oils and non-food vegetable oils have been investigated and considered for a more competitive fuel. Biodiesel from restaurant waste oil is closer to being cost competitive with fossil diesel [5]. Waste cooking oil is much cheaper than virgin oil, but its supply is relatively low, a quantity not enough for the needed amount for industrial and domestic production of biodiesel.

The estimated biodiesel cost is divided into fixed and variable costs. While fixed costs involve cost of oil extraction and process of vegetable oil transformation to biodiesel, variable costs include manufacturing, capital, and labour costs. Furthermore, glycerin (used as starting material in soap and cosmetics industries) and protein meal (used as protein-rich animal supplement) generated as side product can be utilized as poultry feed, sale of which might help to compensate for the cost involved in the production process. Yet, all these measures still do not produce the required incentive for cheaper biodiesel. Optimization of process and operating conditions has been observed to be pertinent in reducing cost associated with production processes [9] [10] [11]. Nevertheless, this is often a rigorous exercise requiring lots of time and effort for procedure repetition. 
Besides, because of the simultaneous effects of some operating variables on the system, optimization procedure has been largely elusive. However, Response Surface Methodology (RSM), as a design and application of modeling tools, is versatile in ensuring product maximization and cost reduction of not only the process, but the product as well [4].

Another important impediment to biodiesel pricing is that petroleum oil derivatives and value-added products are produced in relatively low cost. Nevertheless, recent fall in price of crude oil makes the costs of producing organic diesel less economical compared to those of petroleum-based diesel. Biodiesel cost more than diesel fuel in most diesel market. Currently, at least there exist seven producers of biodiesel in commercial scale in the United States. Pure biodiesel (B100) cost about US $\$ 1.50$ to US $\$ 2.00$ per gallon prior to taxation. Fuel taxes increases the cost to about $25 \%-30 \%$ per gallon [5]. Other reactant in biodiesel synthesis that determines cost is the alcohol used. Methanol is cheap and readily affordable in chemical industries. It is sourced from natural gas. Methanol is valued at around $€ 250$ to $€ 280$ per ton, though the price depends on natural gas prices, which in some ways determines the price of biodiesel.

Furthermore, catalyst is fundamental in the reaction to generate biodiesel and can significantly affect biodiesel pricing. However, the catalyst used differs from one biodiesel processing plant to another. Caustic soda, caustic potash and sulfuric acid are three commonly utilized in biodiesel processing. Other essential contributors to biodiesel production costs are the yield and purity of the byproducts from biodiesel production. Glycerol is produced as a co-product with biodiesel, and its economic worth is of enormous advantage capable of augmenting the cost relief for biodiesel. For every 10 tons of biodiesel produced, 1 ton of glycerol is generated [12]. Glycerol is produced in typical biodiesel plant which is about $80 \%$ pure. The cost of one ton is about $€ 500$. Prospect of glycerol in oleo-chemical industries will assist the development as further investment stands to reduce the production cost of biodiesel industries. Long term expectations project a reduction in production costs by more than $50 \%$ to around ca. $€ 0.20$ per liter (or around $6 € / \mathrm{GJ}$ ) depending on how well the process is optimized.

An investigated feasibility study revealed that the forecasted prices for biodiesel of oil and fats origin range from US $\$ 0.30$ to 0.69 per liter. Price estimates of vegetable oil and waste frying oil biodiesel are between US $\$ 0.54-0.62$ per liter and US $\$ 0.34-0.42$ per liter respectively. With pre-tax policies, diesel is priced at US $\$ 0.18 / \mathrm{L}$ in the USA and about US $\$ 0.20$ to $0.24 / \mathrm{L}$ in some European countries. Therefore, needs for economically competitive organic diesel fuel beckon intensified research holistically [5] [13] [14]. Among the techniques adopted by researchers for a more cost effective and economical biodiesel fuel is to utilize non-edible virgin oil such as Jatropha curcas. Recently, Jatropha curcas has attracted substantive interest as biodiesel feedstock due to its potentials as oil crop feedstock for biodiesel production [15] [16] [17]. This oil crop is a-branched triglycerides with alkyl esters properties like fossil diesel and it is capable of reduc- 
ing $\mathrm{CO}_{2}$ emission to the surrounding when utilized in diesel engine. Although the direct use of the oil is known to cause some problems because of its viscosity and chemical structure [18]. Thus, reduction of its viscosity is of prime importance which has been achieved through chemical and enzymatic transesterification approaches utilizing arrays of catalyst [19].

Optimizing production processes and resources is one important area that is expected to ensure a competitive diesel fuel production. While lots of work has been done in this regard, less effort has been directed to its implication on biodiesel pricing. This has advantage to minimize material lost and enhance the purity of the product by eliminating wastage of resources [20]. Robust production process can as well ensure that product generation is maximized with little or no side reaction, which could otherwise result in waste generation. Very few resources have been found in literature relating the cost of biodiesel to the optimized condition of the process. This paper is aimed at presenting the cost implication for biodiesel as a result of optimized conditions in Jatropha biodiesel production.

\section{Material and Methods}

\subsection{Materials}

The free fatty acid used in the study was a product of enzymatic hydrolysis of the crude Jatropha curcas oil by a locally produced Candida cylindracea lipase. Hydrolysis of Crude J. curcas oil to produce FFA was carried out using immobilized C. cylindracea lipase which resulted in 78\% FFA of the feedstock. This hydrolysate (FFA) was esterified with Methanol procured from HmbG Germany as the acyl acceptor due to cost consideration in the presence of powdered niobium (v) oxide procured from Sigma-Aldrich, USA as the heterogeneous acid catalyst to produce methyl ester. Details of the hydrolysate production are explained in our sister article elsewhere [21].

\subsection{Calcination and Characterization of Niobic Acid Catalyst}

The niobic acid $\left(\mathrm{Nb}_{2} \mathrm{O}_{5} \cdot \mathrm{H}_{2} \mathrm{O}\right)$ catalyst used in this step was calcined at $150^{\circ} \mathrm{C}$ in Iso Temp-220 furnace for $4 \mathrm{hrs}$. The white fluffy niobic acid powder was kept in a desiccator until needed for use. The calcined catalyst was characterized with Fourier Transform Infrared Spectroscopic (FT-IR) analysis (IR prestige-21, FTIR-84005, SHIMADZU Corporation Kyoto, Japan). The functional groups present in the material and FTIR spectra of the sample were recorded within 400 - $4000 \mathrm{~cm}^{-1}$. The transmission spectra of the sample were recorded using the $\mathrm{KBr}$ pellet. About $1.0 \%-2.0 \%$ of the sample was mixed with dry $\mathrm{KBr}$ and grinded in mortar. Then the sample was transferred to hydraulic press. The pressure in hydraulic pump was increased until it reaches 20,000 prf and then the pressure was slowly released. The pellet which is homogeneous and transparent in appearance was inserted into the IR sample holder for the analysis. The pellet was dried overnight at $100^{\circ} \mathrm{C}$ before the spectra were recorded. Detail elsewhere [22]. 


\subsection{Experimental Design of Esterification Reaction}

The batch esterification reaction was carried out in $250 \mathrm{~mL}$ screwed cap flask and the content of the flask was made to react by monitoring the operating parameters in an incubator shaker (INFORS AG CH-4103 BOTTMINGEN). Jatropha curcas hydrolysate (FFAs) (16 g) produced from enzymatic hydrolysis reaching $78 \%$ FFA content was used in the study. After completion of every cycle, the product was centrifuged in a Rotina 38 "Zentrifugen" (D-78532 Tuttlingen) at $4000 \mathrm{rpm}$ for 10 mins. The oil and unreacted methanol phase was decanted into a separating funnel and was left overnight to separate the oil and excess methanol. The fatty acid methyl ester was incubated in drying oven for 3 $4 \mathrm{~h}$ to evaporate the water produced during the esterification procedure. Each experiment was carried out in successive triplicate and then the yield and conversion of the biodiesel were estimated using the equations below.

$$
\text { Yield }(\%)=\frac{\text { weight of biodielsel }}{\text { weight of FFA }} \times 100
$$

and

$$
C=\left(1-\frac{A v_{t}}{A v_{0}}\right)
$$

where $C$ is the FFA conversion to generate FAME, $A v_{t}=$ final acid value and A $v_{0}$ $=$ initial acid value prior to esterification.

Face centered central composite design of Design expert software DoE 6.0.8 [23] was used to determine the interaction of three selected parameters (temperature, catalyst loading and reaction time) for optimum esterification effect based on the observed individual parameter (Table 1). Several batch esterification procedures were investigated for FFA conversion for the three selected parameters (Temperature $55^{\circ} \mathrm{C}-65^{\circ} \mathrm{C}$; catalyst loading $3-5 \mathrm{wt} \%$ and reaction time $5-7$ h). All reactions were carried out using 5:1 methanol molar ratio and agitation of $400 \mathrm{rpm}$.

\section{Result and Discussion}

\subsection{Optimization Study}

In the esterification study, of the five parameters (reaction temperature, molar ratio of methanol, catalyst loading, agitation and reaction time) that were tested for single factor optimization, three prominent variables (reaction temperature, catalyst loading and reaction time) were selected for use in face centered central composite design of design expert 6.0.8 software [23]. The design was used to investigate the parameter interaction for optimum conversion and yield of methyl esters. Table 1 shows the design data for the esterification of hydrolysate.

Results as presented for the experimental matrix (Table 2) show that the yield of biodiesel and the FFA conversion range from $84 \%-95 \%$ and $66 \%-96 \%$, respectively. High biodiesel yield was recorded for different runs (T02, T03, T04, T05, T06, T07, T08, T09, T10 and T15), while for FFA conversion, assays (T02, 
T03, T04, T06, T07, T09, T10, T14 and T20) produced high response. Statistical analysis informs linear contributory effect for the parameters, a quadratic effect for the parameters, as well as for the interaction of catalyst loading with temperature and reaction time with temperature as shown in the $3 \mathrm{D}$ contour plot (Figure 1).

Table 1. Experimental design for esterification reaction.

\begin{tabular}{cccc}
\hline & \multicolumn{3}{c}{ Levels } \\
Variables & -1 & 0 & 1 \\
\cline { 2 - 4 } Temperature $\left({ }^{\circ} \mathrm{C}\right)$ & 55 & 60 & 65 \\
Catalyst loading $(\mathrm{wt} \%)$ & 3 & 4 & 5 \\
Time $(\mathrm{h})$ & 5 & 6 & 7 \\
\hline
\end{tabular}

Table 2. Experimental matrix for the esterification of Jatropha hydrolysate to produce FFA by FCCCD of Design Expert software.

\begin{tabular}{|c|c|c|c|c|c|}
\hline \multirow{2}{*}{ Assay } & \multicolumn{3}{|c|}{ Factors } & \multirow{2}{*}{$\begin{array}{c}\text { Response } 1 \\
\text { \%Yield }\end{array}$} & \multirow{2}{*}{$\begin{array}{l}\text { Response } 2 \\
\text { \%Conversion }\end{array}$} \\
\hline & Temperature & Catalyst loading & React. Time & & \\
\hline T01 & 65 & 5 & 7 & 86 & 88 \\
\hline $\mathrm{T} 02$ & 60 & 4 & 7 & 90 & 92 \\
\hline $\mathrm{T} 03$ & 60 & 4 & 6 & 95 & 96 \\
\hline T04 & 60 & 4 & 6 & 95 & 95 \\
\hline T05 & 65 & 5 & 5 & 92 & 84 \\
\hline T06 & 60 & 4 & 6 & 94 & 96 \\
\hline $\mathrm{T} 07$ & 60 & 4 & 6 & 96 & 95 \\
\hline T08 & 55 & 5 & 5 & 91 & 76 \\
\hline T09 & 60 & 4 & 6 & 94 & 96 \\
\hline $\mathrm{T} 10$ & 60 & 4 & 6 & 95 & 95 \\
\hline $\mathrm{T} 11$ & 55 & 3 & 5 & 84 & 66 \\
\hline $\mathrm{T} 12$ & 55 & 3 & 7 & 82 & 77 \\
\hline $\mathrm{T} 13$ & 65 & 3 & 7 & 86 & 85 \\
\hline $\mathrm{T} 14$ & 60 & 3 & 6 & 89 & 90 \\
\hline $\mathrm{T} 15$ & 60 & 4 & 5 & 90 & 88 \\
\hline $\mathrm{T} 16$ & 55 & 4 & 6 & 86 & 76 \\
\hline $\mathrm{T} 17$ & 65 & 3 & 5 & 85 & 80 \\
\hline $\mathrm{T} 18$ & 60 & 5 & 6 & 88 & 86 \\
\hline $\mathrm{T} 19$ & 55 & 5 & 7 & 84 & 68 \\
\hline $\mathrm{T} 20$ & 65 & 4 & 6 & 87 & 92 \\
\hline
\end{tabular}




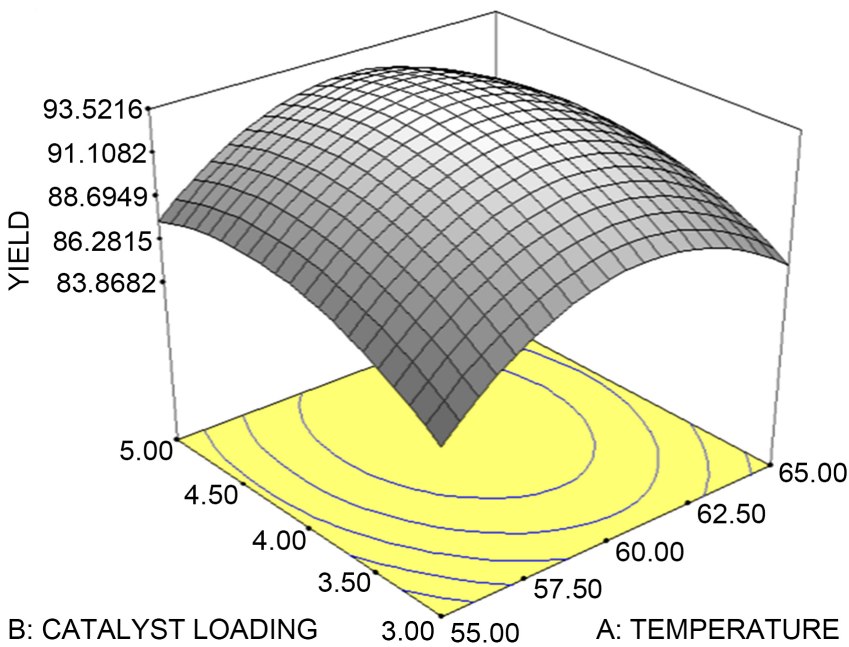

(a)

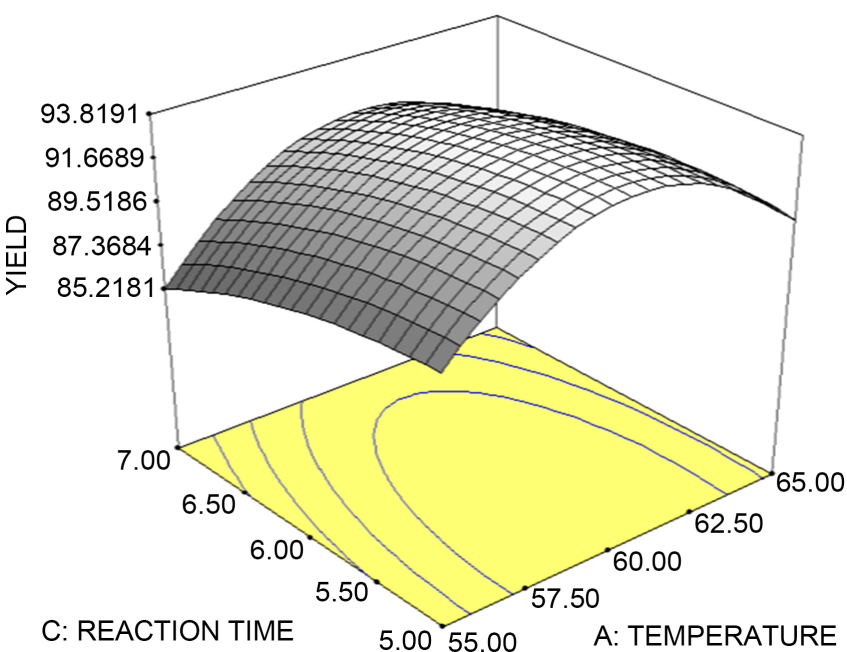

(b)

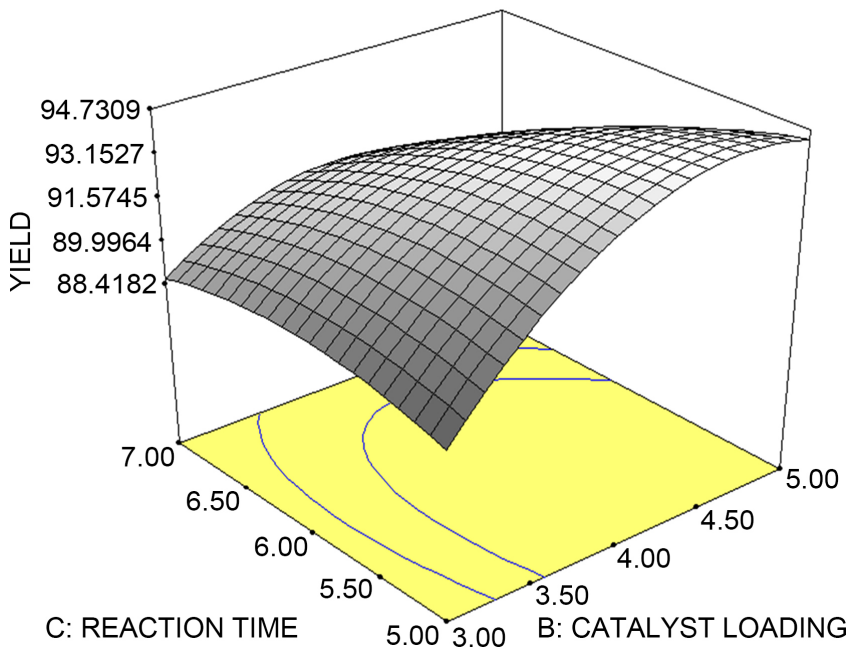

(c)

Figure 1. 3D contour plot showing the interactions of operating parameters on biodiesel yield. (a) Interaction between catalyst loading and temperature; (b) Interaction between time and temperature; and (c) Interaction between catalyst loading and time. 
The factorial design for the biodiesel yield from Jatropha curcas hydrolysate was analyzed with Analysis of Variance (ANOVA). Table 3 presents the result of the analysis of operating parameters contribution to the esterification reaction. ANOVA revealed that the primary contributory effect of the individual parameters statistically influenced the production of biodiesel. Employing the parameters significance, a model was proposed which describes best fitting response function. The model is as presented below:

$\%$ Biodiesel Yield $=+93.25+0.90 \mathrm{~A}+1.50 \mathrm{~B}-1.40 \mathrm{C}$

where $\mathrm{A}=$ temperature, $\mathrm{B}=$ catalyst loading and $\mathrm{C}=$ reaction time. This model is a description of the interaction of the parameters over the boundary considered as confirmed by the Coefficient of Determination $\left(R^{2}\right)$, whose value is 0.8064 in comparison with the adjusted $\left(\mathrm{R}^{2}\right)$ with value of 0.6323 . Statistical implication of the model showed that it was significant at more than $87.4 \%$ confidence level though with significant lack-of-it ( $p>0.05$ ). Besides, $81 \% \mathrm{R}^{2}$ indicated that experimental variability can be explained by the model.

The contour plots (Figure 1(a), Figure 1(b) and Figure 1(c)) present the interactions of the parameters and their effects on the response variable (Biodiesel yield). It is shown that yield of the methyl esters increased with increasing parameters but decrease with further increase reaching $65^{\circ} \mathrm{C}$ for temperature, which may be due to predominant methanol evaporation. Optimum temperature was found to be $60^{\circ} \mathrm{C}$. This ensures a considerate power consumption in the production process thus power utilization will not significantly influence the cost of the product enormously. Contrary to study of [24] where $45^{\circ} \mathrm{C}$ was reported as optimum in alkaline transesterification of papaya seed oil in a transesterification process, however similar value of yield was recorded.

Table 3. Analysis of variance (ANOVA) for Response Surface Quadratic Model [Partial sum of squares] for biodiesel yield.

\begin{tabular}{ccccccc}
\hline Source & $\begin{array}{c}\text { Sum of } \\
\text { squares }\end{array}$ & DF & $\begin{array}{c}\text { Mean } \\
\text { square }\end{array}$ & F value & Prob $>$ F & \\
\hline Model & 294.31 & 9 & 32.70 & 4.63 & 0.0126 & significant \\
A & 8.10 & 1 & 8.10 & 1.15 & 0.3094 & \\
B & 22.50 & 1 & 22.50 & 3.19 & 0.1046 \\
C & 19.60 & 1 & 19.60 & 2.77 & 0.1267 \\
$\mathrm{~A}^{2}$ & 52.36 & 1 & 52.36 & 7.41 & 0.0215 \\
$\mathrm{~B}^{2}$ & 15.36 & 1 & 15.36 & 2.18 & 0.1710 \\
$\mathrm{C}^{2}$ & 2.05 & 1 & 2.05 & 0.29 & 0.6018 \\
$\mathrm{AB}$ & 0.50 & 1 & 0.50 & 0.071 & 0.7956 & \\
$\mathrm{AC}$ & 2.00 & 1 & 2.00 & 0.28 & 0.6063 & \\
$\mathrm{BC}$ & 18.00 & 1 & 18.00 & 2.55 & 0.1415 & \\
\hline
\end{tabular}


Furthermore, increasing the catalyst loading also increased biodiesel yield and further increment above $4 \mathrm{wt} \%$ produced low yield which can be attributed to favoritism of backward reaction causing FFA production. Veena et al. [6] reported $2.5 \%$ optimum catalyst for transesterification of Kusum oil and attributed observed reduction to soap formation with the excess catalyst above the optimum. In this study, $4 \mathrm{wt} \%$ was discovered to be optimum catalyst dose producing up to $96 \%$ yield of methyl ester. Increasing the catalyst further does not show significant increase. Hence, optimum esterification effect was achieved at $4 \mathrm{wt} \%$ of the catalyst. This attainment in catalyst use shows minimum amount ensuring high yield generation of the product.

Nguyen et al. [7] obtained similar amount of yield of biodiesel from insect fat employing enzymatic catalysis at higher reaction time and enzyme loading. Enzyme is prone to deactivation at high FFA content. Our approach of chemical catalysis ensures that the FFAs are effectively converted to FAME without issue relating to enzyme deactivation. The implication of this on the price of the product is that little effect does the catalyst have on the cost of the product because the catalyst dose was small and its improvement through a cost-effective physical modification was as well helpful. Dharma et al. [25] studied optimization of biodiesel from J. curcas using $\mathrm{KOH}$ and recorded $2 \mathrm{~h}$ reaction time at $60^{\circ} \mathrm{C}$ reaction temperature like what was found in this present study. Lower reaction time reported in literature is expected, as many researchers suggested that alkaline catalyst perform better compared to heterogenous catalyst, however, it becomes an issue due to possible saponification with feedstocks of High FFA such as $J$. curcas.

For FFA conversion, the contour plots (Figure 2(a), Figure 2(b) and Figure 2(c)) present the interactions of the parameters and their effects on the FFA conversion. It is shown that esterification increased with increasing parameters but decrease with further increase above $60^{\circ} \mathrm{C}$ for temperature. Optimum temperature was found to be $60^{\circ} \mathrm{C}$. Moreover, increasing the amount of catalyst also favours esterification reaction and further increase above $4 \mathrm{wt} \%$ offered no further increase in the FFA conversion. $4 \mathrm{wt} \%$ of the catalyst was discovered to be optimum for FFA conversion producing up to $96 \%$ FAME. Increasing the catalyst further does not show significant increase. Hence, optimum esterification of the hydrolysate was achieved at $4 \mathrm{wt} \%$ of the catalyst.

Employing the parameters significance, a model was proposed to describe best fitting response function. The model is as follow:

$$
\% \text { FFA Conversion }=+94.48+6.60 \mathrm{~A}+0.40 \mathrm{~B}+1.60 \mathrm{C}
$$

where $\mathrm{A}=$ temperature, $\mathrm{B}=$ catalyst loading and $\mathrm{C}=$ reaction time.

The model is a description of the interaction of the parameters over the boundary considered as confirmed by the Coefficient of Determination $\left(R^{2}\right)$, whose value is 0.9507 compared to the adjusted $\left(R^{2}\right)$ value of 0.9063 (Table 4). Statistical implication of the model showed that it was significant at more than $99 \%$ confidence level though with significant lack-of-it ( $p>0.05$ ). Besides, $81 \%$ $\mathrm{R}^{2}$ indicated that experimental variability can be explained by the model [26]. 


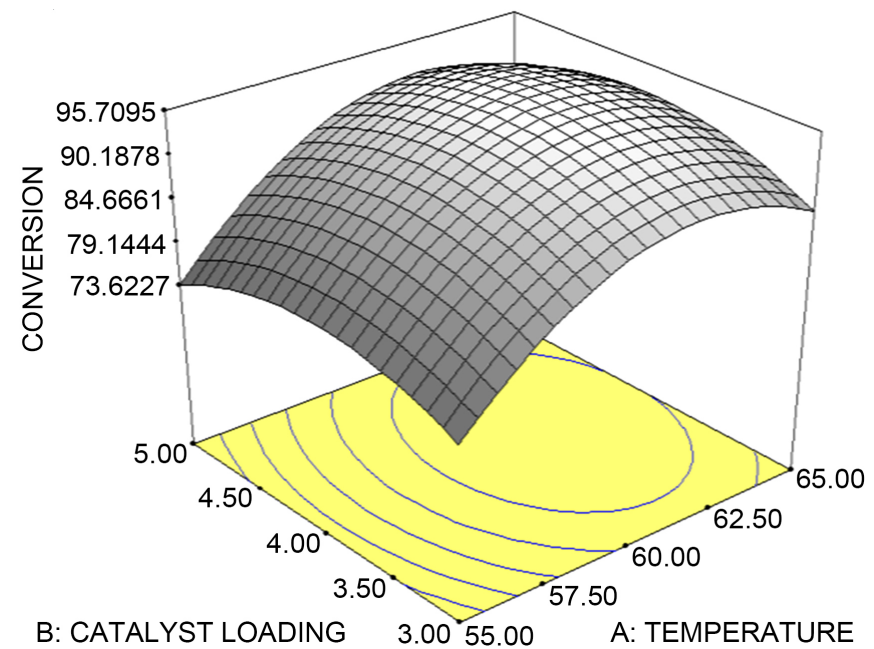

(a)

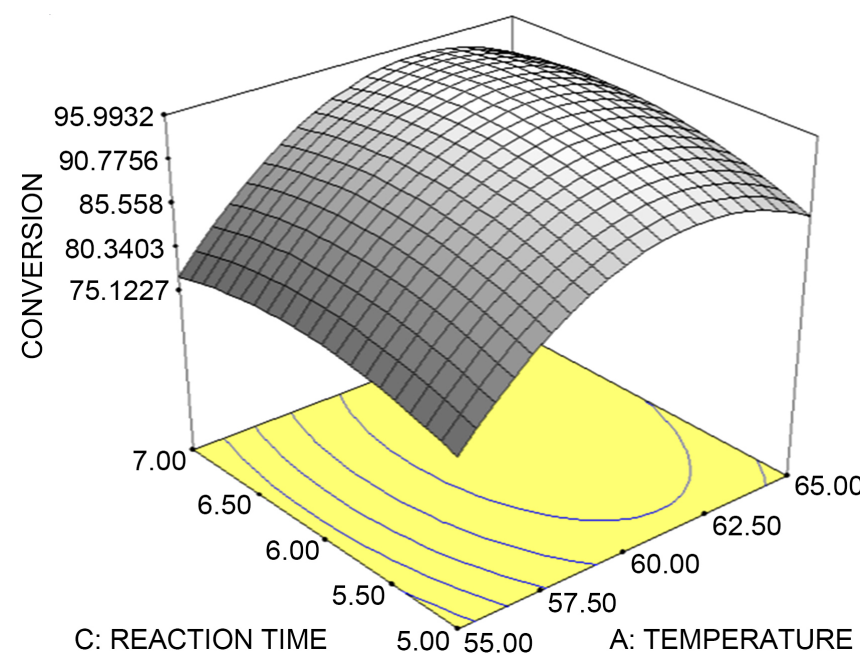

(b)

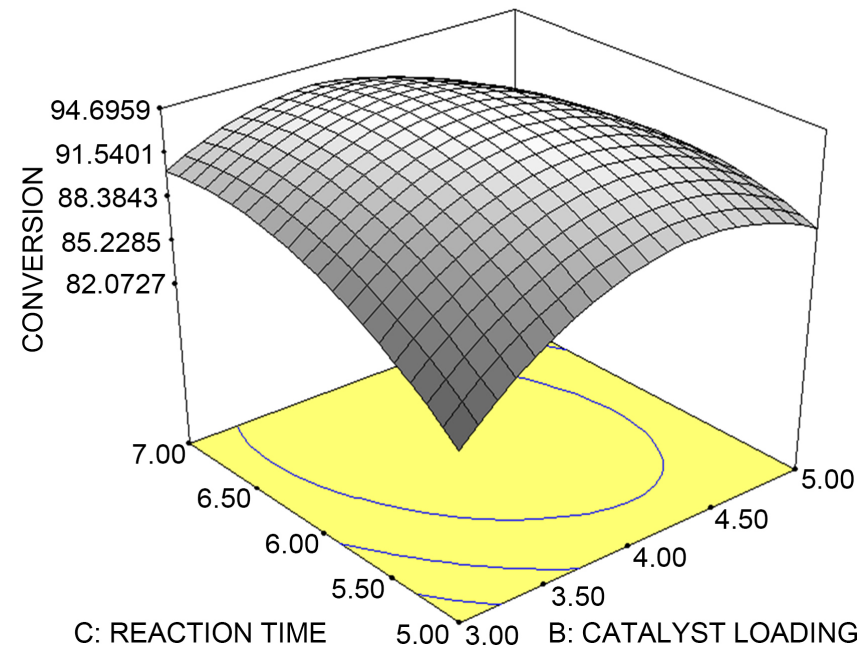

(c)

Figure 2. 3D contour plot showing the interactions of operating parameters on FAME conversion. (a) Interaction between catalyst loading and temperature; (b) Interaction between time and temperature; and (c) Interaction between catalyst loading and time. 
Table 4. Analysis of variance (ANOVA) for Response Surface Quadratic Model [Partial sum of squares] for FFA conversion.

\begin{tabular}{ccccccc}
\hline Source & $\begin{array}{c}\text { Sum of } \\
\text { squares }\end{array}$ & DF & $\begin{array}{c}\text { Mean } \\
\text { square }\end{array}$ & F value & Prob $>$ F & \\
\hline Model & 1601.87 & 9 & 177.99 & 21.42 & $<0.0001$ & significant \\
A & 435.60 & 1 & 435.60 & 52.43 & $<0.0001$ & \\
B & 1.60 & 1 & 1.60 & 0.19 & 0.6701 \\
C & 25.60 & 1 & 25.60 & 3.08 & 0.1097 \\
$\mathrm{~A}^{2}$ & 220.51 & 1 & 220.51 & 26.54 & 0.0004 \\
$\mathrm{~B}^{2}$ & 67.51 & 1 & 67.51 & 8.13 & 0.0172 \\
$\mathrm{C}^{2}$ & 24.01 & 1 & 24.01 & 2.89 & 0.1200 \\
$\mathrm{AB}$ & 4.50 & 1 & 4.50 & 0.54 & 0.4787 \\
$\mathrm{AC}$ & 4.50 & 1 & 4.50 & 0.54 & 0.4787 \\
$\mathrm{BC}$ & 50.00 & 1 & 50.00 & 6.02 & 0.0341 \\
\hline
\end{tabular}

In an optimization study conducted by Meher et al. [27], they estimated between $97 \%$ - 98\% optimum yield of fatty acid methyl ester using Karanja oil as the feedstock. Some researchers recommended two-step approach for synthesis of biodiesel from feedstock of high FFA content to generate better yield, they however submitted to the common esterification of the FFA and subsequent transesterification rather than the recent hydro-esterification where more of FFA is produced and then esterification carried out [28] [29].

\subsection{Economic Analysis and Scale-Up Propensity of Jatropha Biodiesel}

The economic analysis of the synthesized biodiesel can be effectively compared with the various submission proposed by Karmee et al. [30]. The study utilized waste cooking oil (WCO) as feedstock to offset the feedstock price of virgin vegetable oil $( \pm \$ 1.01 / \mathrm{L})$ comparatively with the feedstock employed in this study (Jatropha curcas oil $(J C O)$ ) with average price of $(\$ 2.39 / \mathrm{L})$. Besides, the study of Karmee et al. reported a 6\% FFA content of the WCO which is comparable with the 7\% initial FFA content of the JCO reported elsewhere [31]. The reaction conditions were as well similar to the reported estimation of $65^{\circ} \mathrm{C}$ temperature, 6 $\mathrm{h}$ reaction time and catalyst loading of $5 \mathrm{wt} \%$. This study employed an average 6 h Reaction time and approximately $4 \mathrm{wt} \%$ of the catalyst which is appreciably lower than that reported by [30] a development that is expected to further reduce the price of the synthesized Jatropha biodiesel.

The scale-up of the Jatropha biodiesel is recommended based on the optimum condition with which the biodiesel had been synthesized. The Jatropha biodiesel can be produced to several thousands of Litres subject to the availability of the 
feedstock which is the major drive. The production route was discovered to be environmentally feasible and the pure synthesized glycerol which can be used by oleo chemical industries will further provide a value-added augmentation to cost of production. The only expensive Reagent utilized in the study was the chemical catalyst (niobic acid), however, research is underway to investigate the activity of low cost heterogeneous catalyst derived from biomass resource for esterification of the hydrolysate produced from hydrolysis of the crude Jatropha curcas.

\section{Conclusion}

In this study, Response surface methodology (RSM) was successfully applied to study the effects of the key operating parameters on Jatropha biodiesel yield and conversion. ANOVA results showed that temperature effect was the most prominent for FAME conversion, as well as for the yield with an optimum temperature value of $60^{\circ}, 4 \mathrm{wt} \%$ for catalyst loading and $6 \mathrm{~h}$ reaction time. In addition, the interactive effect of catalyst loading/reaction time was found to be incredibly significant on both responses. The maximum biodiesel yield and FAME conversion under the optimum condition was $96 \mathrm{wt} \%$ and $96 \%$ FFA conversion. Furthermore, the optimization study was discovered to achieve minimum resource utilization implying an offshoot for the price of the biodiesel fuel produced from the process. While development of low-cost heterogeneous catalyst especially from waste materials is anticipated to further ensure cost competitiveness, optimization of the production process has been shown to be significant for product pricing. Hence the two-step hydro-esterification is a viable and promising approach for biodiesel synthesis from oil resources with extremely high FFA content.

\section{Acknowledgements}

The study was supported with a financial aid from IIUM endowment B project research grant with project NO: EDW B-12-378-0856 for which the authors are indebted.

\section{Highlights}

- Optimization study of Jatropha curcas oil by face centered central composite design (FCCCD).

- High Yield and conversion of Jatropha biodiesel by two stage production approach.

- Determination of optimum values for both yield and conversion of Jatropha biodiesel at minimum resource utilization.

- Statistical implication of the model significance at high confidence level and implication for product pricing.

\section{Conflicts of Interest}

The authors declare no conflicts of interest regarding the publication of this paper. 


\section{References}

[1] Martini, N. and Schell, S. (1998) Plant oil as Fuels: Present State of Future Developments. In: Proceedings of the Synopsis, Springer, Berlin, 6.

https://doi.org/10.1007/978-3-642-72269-1

[2] Antolin, G., Tinaut, F., Briceno, Y., Castano, V., Perez, C. and Ramirez, A. (2002) Optimization of Biodiesel Production by Sunflower Oil Transesterification. Bioresource Technology, 83, 111-114. https://doi.org/10.1016/S0960-8524(01)00200-0

[3] Vicente, G., Martinez, M. and Aracil, J. (2004) Integrated Biodiesel Production: A Comparison of Different Homogeneous Catalyst Systems. Bioresource Technology, 92, 297-305. https://doi.org/10.1016/j.biortech.2003.08.014

[4] Hoda, H., Mandana, A. and Farshad, Y. (2015) Optimization of Biodiesel Production from the Waste Cooking Oil Using Response Surface Methodology. Process Safety and Environmental Protection, 94, 1-10. https://doi.org/10.1016/j.psep.2014.12.005

[5] Demirbas, A. (2008) Biodiesel: A Realistic Fuel Alternative for Diesel Engine. Springer, Berlin.

[6] Singh, V., Lyubov, B., Bhaskar, S. and Yogesh, C.S. (2018) Biodiesel Production Using a Novel Heterogeneous Catalyst, Magnesium Zirconate $\left(\mathrm{Mg}_{2} \mathrm{Zr}_{5} \mathrm{O}_{12}\right)$ : Process Optimization through Response Surface Methodology (RSM). Energy Conversion and Management, 174, 198-207. https://doi.org/10.1016/j.enconman.2018.08.029

[7] Nguyen, H.C., Shih-Hsiang, L., Shang, S.C., Chia, H.S., Jhih-Huei, L. and Chien-Chung, C. (2018) Enzymatic Production of Biodiesel from Insect Fat Using Methyl Acetate as an Acyl Acceptor: Optimization by Using Response Surface Methodology. Energy Conversion and Management, 158, 168-175.

https://doi.org/10.1016/j.enconman.2017.12.068

[8] Demirbas, A. (2005) Biodiesel Production from Vegetable Oils via Catalytic and Non-Catalytic Supercritical Methanol Transesterification Methods. Progress in Energy and Combustion Science, 31, 466-487. https://doi.org/10.1016/j.pecs.2005.09.001

[9] Hojjat, M., Nayebzadeh, H., Khadangi-Mahrood, M. and Rahmani-Vahid, B. (2017) Optimization of Process Conditions for Biodiesel Production over $\mathrm{CaO}-\mathrm{Al}_{2} \mathrm{O}_{3} / \mathrm{ZrO}_{2}$ Catalyst Using Response Surface Methodology. Chemical Papers, 71, 689-698. https://doi.org/10.1007/s11696-016-0096-1

[10] Athar, M., Zaidi, S. and Hassan, S.Z. (2020) Intensification and Optimization of Biodiesel Production Using Microwave-Assisted Acid-Organo Catalyzed Transesterification Process. Scientific Reports, 10, 212-239.

https://doi.org/10.1038/s41598-020-77798-1

[11] Ajala, E.O., Aberuagba, F., Olaniyan, A.M., Ajala, M.A. and Sunmonu, M.O. (2017) Optimization of a Two-Stage Process for Biodiesel Production from Shea Butter Using Response Surface Methodology. Egyptian Journal of Petroleum, 26, 943-955. https://doi.org/10.1016/j.ejpe.2016.11.005

[12] Aranda, D.A.G., da Silva, C.C.C. and Detoni, C. (2009) Current Processes in Brazilian Biodiesel Production. International Review of Chemical Engineering, 1, 603-608.

[13] Bender, M. (1999) Economic Feasibility Review for Community-Scale Farmer Cooperatives for Biodiesel. Bioresource Technology, 70, 81-87. https://doi.org/10.1016/S0960-8524(99)00009-7

[14] Demirbas, A. (2003) Biodiesel Fuels from Vegetable Oils via Catalytic and Non-Catalytic Supercritical Alcohol Transesterifications and Other Methods: A Survey. Energy 
Conversion and Management, 44, 2093-2109.

https://doi.org/10.1016/S0196-8904(02)00234-0

[15] Jongschaap, R.E.E., Corré, W.J., Bindraban, P.S. and Brandenburg, W.A. (2007) Claim and Facts on Jatropha curcas L. Plant Research International, B.V., Wageningen.

[16] King, A., He, W., Cuevas, J., Freudenberger, M., Ramiaramanana, D. and Graham, I. (2009) Potential of Jatropha curcas as a Source of Renewable Oil and Animal Feed. Journal of Experimental Botany, 60, 2897-2905.

https://doi.org/10.1093/jxb/erp025

[17] Divakara, B.N., Upadhyaya, H.D., Wani, S.P. and Gowda, C.L.L. (2010) Biology and Genetic Improvement of Jatropha curcas L.: A Review. Applied Energy, 87, 732-742. https://doi.org/10.1016/j.apenergy.2009.07.013

[18] Wardana, I.N.G. (2010) Combustion Characteristics of Jatropha Oil Droplet at Various Oil Temperatures. Fuel, 89, 659-664.

https://doi.org/10.1016/j.fuel.2009.07.002

[19] Kamil, M., Nik, R., Yusup, S. and Umer, R. (2011) Optimization of Polyol Ester Production by Tranesterfication of Jatropha-Based Methyl Ester with Trimethylolpropane Using Taguchi Design Experiment. Fuel, 90, 2343-2345.

https://doi.org/10.1016/j.fuel.2011.02.018

[20] Krishnamurthy, K.N., Sridhara, S.N. and Ananda Kumar, C.S. (2018) Synthesis and Optimization of Hydnocarpus wightiana and Dairy Waste Scum as Feed Stock for Biodiesel Production by Using Response Surface Methodology. Energy, 153, 1073-1086. https://doi.org/10.1016/j.energy.2018.04.068

[21] Kabbashi, N.A., Mohammed, N.I., Alam, M.Z. and Mirghani, M.E.S. (2015) Hydrolysis of Jatropha curcas Oil for Biodiesel Synthesis Using Immobilized Candida Cylindracea Lipase. Journal of Molecular Catalysis B: Enzymatic, 116, 95-100. https://doi.org/10.1016/j.molcatb.2015.03.009

[22] Mohammed, N.I., Kabbashi, N.A., Alam, M.Z. and Mirghani, M.E.S. (2016) Esterification of Jatropha curcas Hydrolysate Using Powdered Niobic Acid Catalyst. Journal of the Taiwan Institute of Chemical Engineers, 63, 243-249. https://doi.org/10.1016/j.jtice.2016.03.007

[23] Stat-Ease (2002) Design Expert, Version 6.0.8. Stat-Ease Inc., East Hennepin Avenue. http://www.statease.com

[24] Mohammad, A., Mohammad, G.R. and Nanjappa, A. (2018) Production Optimization and Quality Assessment of Papaya (Carica papaya) Biodiesel with Response Surface Methodology. Energy Conversion and Management, 156, 103-112. https://doi.org/10.1016/j.enconman.2017.11.004

[25] Dharma, S., Masjuki, H.H., Hwai, C.O., Sebayang, A.H., Silitonga, A.S., Kusumo, F. and Mahia, T.M.I. (2016) Optimization of Biodiesel Production Process for Mixed Jatropha curcas-Ceiba pentandra Biodiesel Using Response Surface Methodology. Energy Conversion and Management, 115, 178-190. https://doi.org/10.1016/j.enconman.2016.02.034

[26] Montgomery, D.C. (2005) Design and Analysis of Experiments 13, 35, 164, 247, 286. John Wiley \& Sons, Inc., Hoboken.

[27] Meher, L., Dharmagadda, V. and Naik, S. (2006) Optimization of Alkali-Catalyzed Transesterification of Pongamia pinnata Oil for Production of Biodiesel. Bioresource Technology, 97, 1392-1397. https://doi.org/10.1016/j.biortech.2005.07.003

[28] Van Gerpen, J. and Canakci, M. (2001) Biodiesel Production from Oils and Fats with High Free Fatty Acids. Transactions of the ASAE, 44, 1429-1436. 
https://doi.org/10.13031/2013.7010

[29] Ramadhas, A.S., Jayraj, S. and Muraleedharan, C. (2005) Biodiesel Production from High FFA Rubber Seed Oil. Fuel, 84, 335-340.

https://doi.org/10.1016/j.fuel.2004.09.016

[30] Karmee, S.K., Patria, R.D. and Ki Lin, C.S. (2015) Techno-Economic Evaluation of Biodiesel Production from Waste Cooking Oil-A Case Study of Hong Kong. International Journal of Molecular Sciences, 16, 4362-4371.

https://doi.org/10.3390/ijms16034362

[31] Mohammed, N.I., Kabbashi, N.A., Alam, Md.Z. and Mirghani, M.E.S. (2014) Jatropha curcas Oil Characterization and Its Significance for Feedstock Selection in Biodiesel Production. IPCBEE, 65, 57-62. 